\title{
Some blood values in cows diagnosed clinically as ephemeral fever
}

\author{
Jameel G.H. ${ }^{1}$; Hasan A. SH. ${ }^{2}$; Jawad S.J. ${ }^{1}$
}

1- College of Education-Diyala University 2- College of Veterinary Medicine-Diyala University, Iraq

\section{Summary}

Sixty cows were included in this study which was conducted in Baquba for the period from April 2011 to October 2011. They were clinically diagnosed as having bovine ephemeral fever (BEF) infection. Blood samples were collected from infected cows before, after treatment, and after recovery. Additionally, 30 healthy cows were included as control group. Sera were separated and submitted for the determination of phosphorus, glucose, cholesterol and $\mathrm{pH}$ levels. Statistical analysis of biochemical values revealed significant decrease in serum cholesterol levels in infected cows as compared to control group $(\mathrm{P}<0.05)$. Furthermore, the diseased cows showed low levels of $\mathrm{pH}$ (acidosis), thus when they treated by intravenous injection of $5 \%$ sodium bicarbonate, the signs were rapidly subsided and the cows were completely recovered.

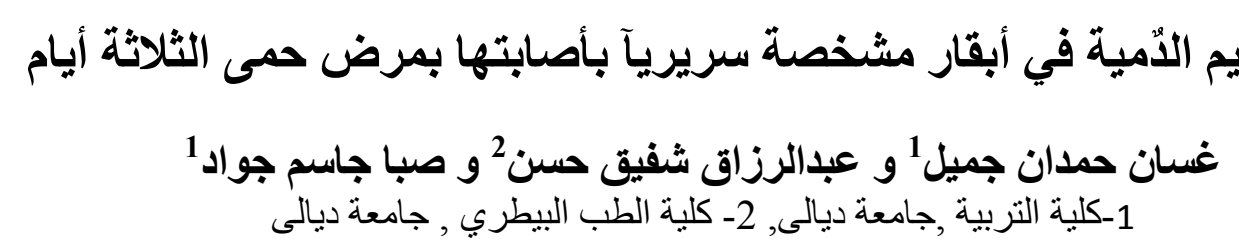

\section{الخلاصة}

أجريت الدراسة للفترة من شهر نيسان 2011 الى شهر تشرين الاول 2011 في محافظة ديالى على 60 بقرة مصابة

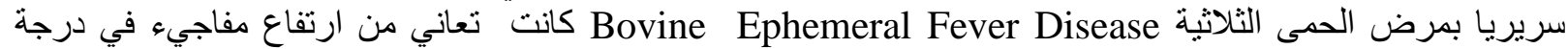

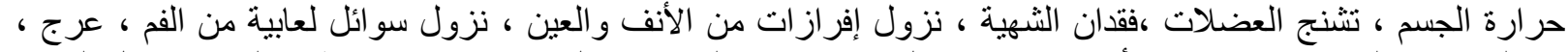

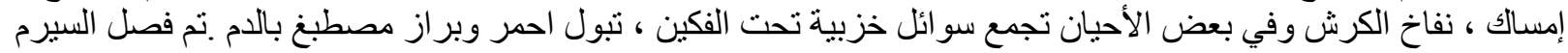

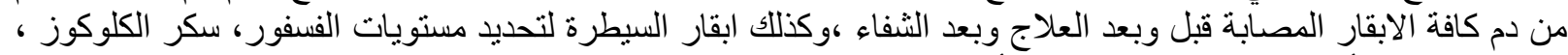

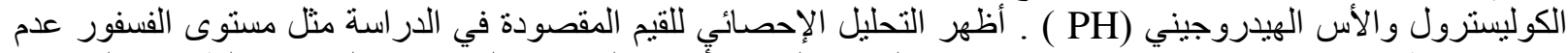

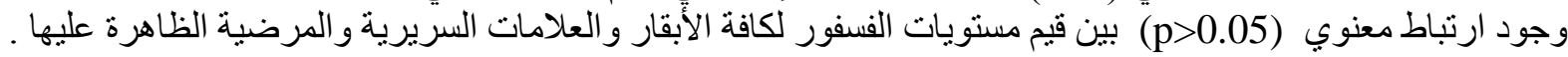

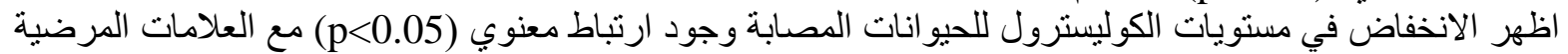

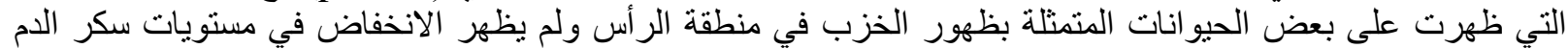
glucose

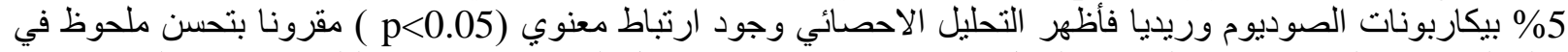
حالة الحيو انات الصحية بدء" بالتغوطو والتبول ثم الاجترار وبطى الإيء في تناول الطعام بعد ساعات قليلة من اعطاء العلاج.

\section{Introduction}

Bovine ephemeral fever (BEF) or three day sickness is a non contagious epizootic arthropod - borne viral disease of cattle and water buffalos besides subclinical involvement of a variety of ruminant species (1). The BEF virus belongs to Ephemerovirus of the Rhabdoviridae family which is a single - stranded RNA, ether - sensitive Rhabdovirus with five structural proteins (2,3). Epizootic evidence indicates that BEF virus is spread by an insect bite, and it is clear from the distribution that more than one vector is capable of transmitting the disease. (4). The disease is characterized by sudden onset fever, depression, stiffness, lameness, nasal and ocular discharge, and salivation. It has been reported that the clinical signs of ephemeral fever were related to biochemical, cellular and serological changes in the blood. There was a rise in peripheral blood neutrophils and fall in lymphocytes counts, a fall in serum calcium levels that directly proportionate with severity of the clinical picture. The serum magnesium levels were slightly affected, with the marked elevation of plasma fibrinogen on the second day of disease (5). 


\section{Proceeding of the Eleventh Veterinary Scientific Conference, 2012; 190-193}

The disease causes significant economic impact through reduced milk production in dairy herds, loss of condition in beef cattle and loss of draught animals at the time of harvest (6). Various diseases may be clinically confused with ephemeral fever for example, blue tongue, botulism, babesiosis, and black leg. ELISA is an inexpensive and rapid serological detection method that is suitable for screening for BEFV infection on a large scale (7). It has been indicated that treatment with phenylbutazone sodium blocked the host response which produces the clinical signs and did not have an anti-viral effect, thus treatment with phenylbutazone sodium and calcium borogluconate was favorable (8). The present study aimed to reveal the effect of bovine ephemeral fever infection on certain blood biochemicals such as phosphorus, cholesterol, glucose and $\mathrm{pH}$ in infected cows in Diyala province.

\section{Materials and Methods}

Sixty cows of both sexes were includes in this study. Their ages ranged from 6 months to 4 years. These cows were brought sporadically to private veterinary clinic in Baquba during an outbreak of EF infection that occurs from April 2011 to September 2011. All were clinically diagnosed as having EFV infection. They were divided to two groups: the treated group; includes thirty cows which were treated as follows:

A. Anti-pyretic, antibacterial drugs were given as dipyrone $50 \%$ and a combination of sulfadiazine $20 \%$ and trimethoprim $40 \%$, at a dose of $1 \mathrm{ml} / 10 \mathrm{~kg}$ body weight for two days by intramuscular injection.

B. Sodium bicarbonate $5 \%$ as a single intravenous injection at a dose $1 \mathrm{ml} / 10 \mathrm{~kg}$ body weight.The second group includes thirty infected cows which were treated by oral administration of a mixture of magnesium carbonate $90 \mathrm{gm}$, sodium carbonate10 $\mathrm{gm}$ and nuxvomica $1 \mathrm{gm}$, in addition to other drugs which included in item A above.

Five milliliters of venous blood was aspirated aseptically from the jugular vein of all cows included in this study. Blood smear was done for each blood sample and stained by Geimsa's stain. The blood samples were left in room temperature for 15-20 minutes to clot, and sent to the laboratory by cool box. The blood samples were centrifuged at 3000 rotation/minute for 5 minutes, and the sera were separated and kept frozen until used. Urine samples were also collected especially from cows with red urine for general urine analysis. Commercially available biochemical kits were used to determine blood sugar (Randox-UK), Phosphorus and cholesterol (Spinreact- Spain). The statistical analyses were done using (F- test). P values less than 0.05 were considered significant.

\section{Results}

Table (1) revealed the mean \pm SD of the phosphorus, cholesterol, glucose and PH levels in sera of infected animal groups (treated and control).

Table (1): Serum phosphorus, glucose, cholesterol and pH among study groups.

\begin{tabular}{|l|l|l|l|l|c|}
\hline Animals groups & No. & \multicolumn{1}{|c|}{$\begin{array}{c}\text { Phosphorus } \\
(\mathrm{mg} / \mathrm{dl})\end{array}$} & $\begin{array}{c}\text { Glucose } \\
(\mathrm{mg} / \mathrm{dl})\end{array}$ & $\begin{array}{c}\text { Cholestrol } \\
(\mathrm{mg} / \mathrm{dl})\end{array}$ & PH \\
\hline $\begin{array}{l}\text { Infected animals } \\
\text { (at febrile stage) }\end{array}$ & 10 & $4.59 \pm 1.14$ & $79.1 \pm 1.01$ & $61.1 \pm 0.02$ & $5.14 \pm 0.03$ \\
\hline $\begin{array}{l}\text { Infected animal } \\
\text { after treatment }\end{array}$ & 10 & $4.60 \pm 0.21$ & $81.5 \pm \mathbf{0 . 3}$ & $\mathbf{7 2 . 6} \pm 1.33$ & $\mathbf{8 . 9} \pm 1.02$ \\
\hline After recovery & 10 & $4.62 \pm 0.04$ & $66.4 \pm 1.37$ & $107.9 \pm 1.112 *$ & $6.91 \pm 1.24$ \\
\hline Control group & $\mathbf{3 0}$ & $4.37 \pm \mathbf{0 . 0 2}$ & $\mathbf{7 8 . 3} \pm \mathbf{0 . 0 4}$ & $\mathbf{6 9 . 7} \pm \mathbf{0 . 1 3}$ & $\mathbf{5 . 8} \pm \mathbf{0 . 0 1}$ \\
\hline
\end{tabular}

$(\mathbf{P}<0.05) *$

The means value of the phosphorus levels were $(4.59 \pm 1.14 \mathrm{mg} / \mathrm{dl}),(4.60 \pm 0.21 \mathrm{mg} / \mathrm{dl})$, and $(4.62 \pm 0.04 \mathrm{mg} / \mathrm{dl})$ in infected animals before and after treatment, and after recovery respectively, compared to $(4.37 \pm 0.02 \mathrm{mg} / \mathrm{dl})$ in control group. The means value of glucose 


\section{Proceeding of the Eleventh Veterinary Scientific Conference, 2012; 190-193}

levels were $(79 \pm 1.01 \mathrm{mg} / \mathrm{dl}),(81.5 \pm 0.3 \mathrm{mg} / \mathrm{dl})$, and $(66.4 \pm 1.37 \mathrm{mg} / \mathrm{dl})$ in infected animals before and after treatment and after recovery respectively, compared to $(78.3 \pm 0.04 \mathrm{mg} / \mathrm{dl})$ in control cows, without any significant difference $(\mathrm{P}>0.05)$. The means value of cholesterol levels were $(61.1 \pm 0.02 \mathrm{mg} / \mathrm{dl})$ in infected animals, and $(72.6 \pm 1.33 \mathrm{mg} / \mathrm{dl})$, and $(107.9 \pm 1.11 \mathrm{mg} / \mathrm{dl})$ before and after treatment and after recovery respectively, and $(69.7 \pm 0.13 \mathrm{mg} / \mathrm{dl})$ in control group. There is slight decrease in cholesterol levels from the normal value $(66-298 \mathrm{mg} / \mathrm{dl})$ in infected animals in stage of pyrexia, while it is raised to normal levels in recovered animals.

The means value of blood $\mathrm{pH}$ levels were $(5.1 \pm 0.03)$, and $(8.9 \pm 1.02)$, and $(6.9 \pm 1.24)$ before and after treatment and after recovery respectively, and (5.8 \pm 0.01$)$ in control group.

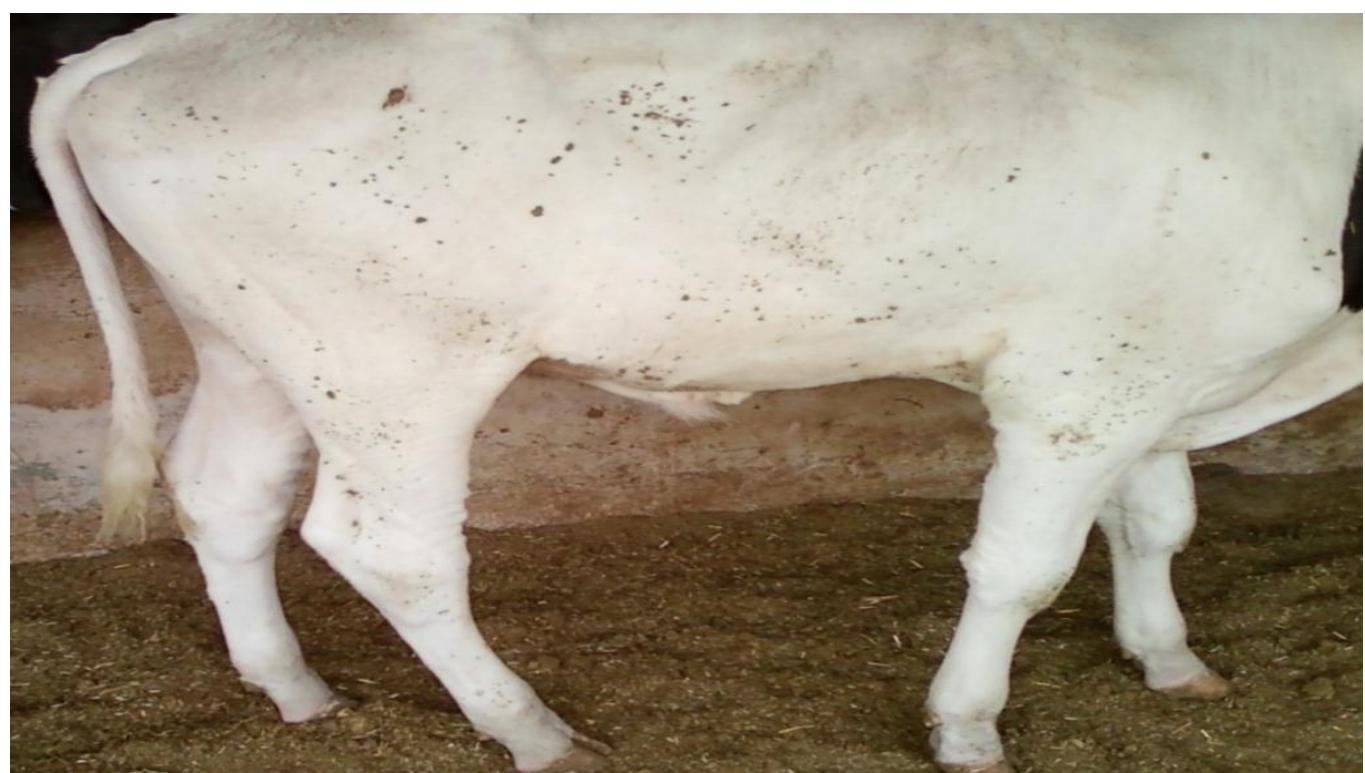

Figure (1): Muscle stiffness, and lameness in right forelimb and hind limb

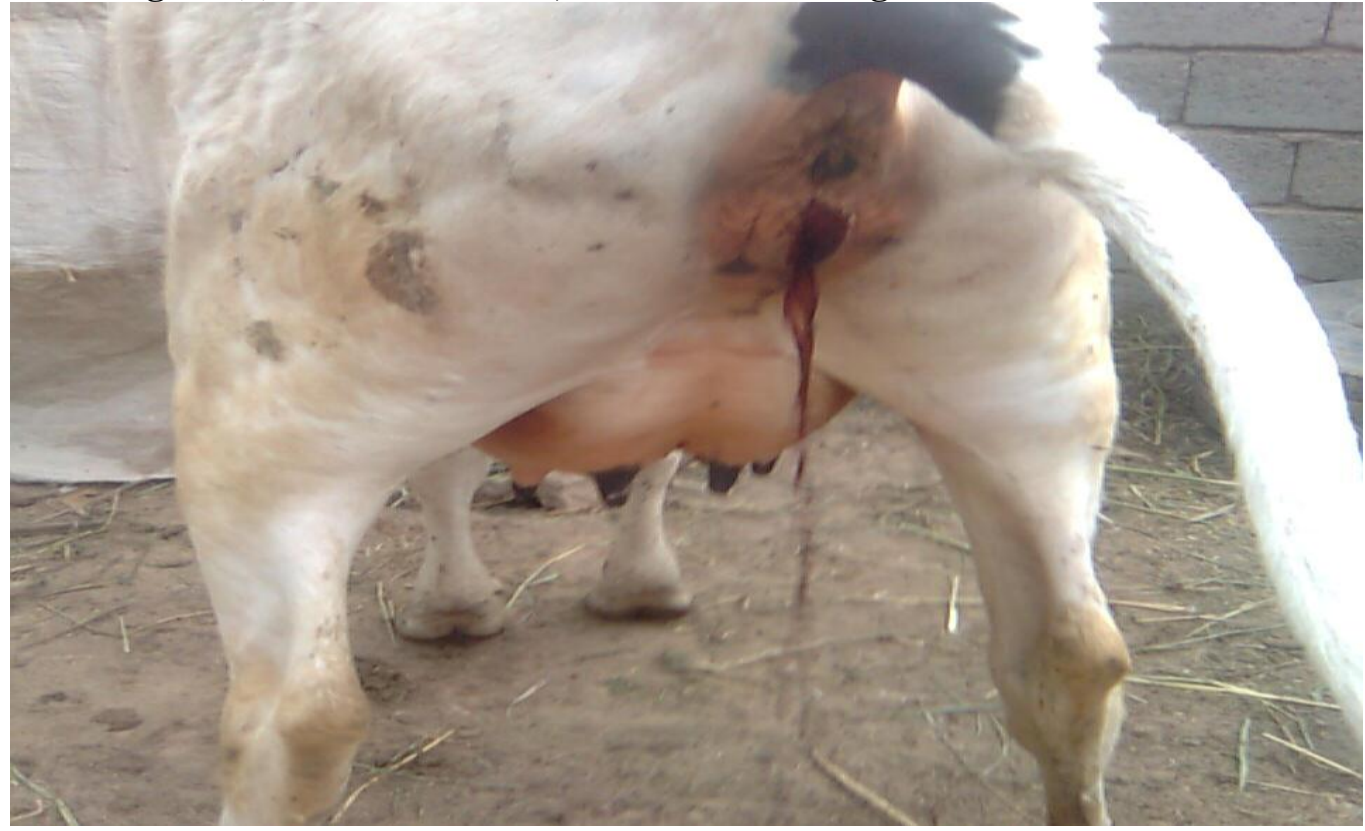

Figure (2): red water urination in infected cow

\section{Discussion}

The results in the present study showed insignificant difference in the mean levels of serum phosphorus and glucose between diseased and healthy animals. However, other workers have reported a sharp decline in phosphorus levels in diseased cows (9). The results also 


\section{Proceeding of the Eleventh Veterinary Scientific Conference, 2012; 190-193}

revealed slight decrease in the cholesterol levels in diseased cows, which restore after recovery. Cholesterol is referred as an amphipathic molecule, that it contains hydrophilic and hydrophobic parts, making it a key regulator of membrane fluidity in animal cells (10). Cholesterol interfere with stiffness of the muscles, and hypocalcaemia, means the calcium ions are very important in muscle contraction and relaxation $(6,8)$.

The prominent feature in diseased cows observed in this study is the lowering of $\mathrm{pH}$, which become normal after treatment and recovery. Lowering of $\mathrm{pH}$ levels usually leads to acidosis that arises due to high grain feeding. Accumulation of grain in rumen of animals together with elevated body temperature predispose to rumen cessation followed by indigestion and developed to constipation and may be emphysema (11).

It has been documented that the ephemeral fever virus lost its infectivity after 90 minutes at $\mathrm{pH}$ (9.1) (12). While other worker documented that full penetration of the virus through endosomal pathway occur in $\mathrm{pH}(\leq 5-6)(10)$. However, inactivation of ephemeral fever virus was found to be occurred in low $\mathrm{pH}$ (13). Some veterinarian tried to treat the rumen cessation by oral administration of laxative and carminative drugs as magnesium carbonate, sodium carbonate and nuxvomica that may be helpful. Our clinical experience in treatment of the rumen cessation by $5 \%$ sodium bicarbonate intravenously to correct metabolic acidosis was based on the concept that the sodium bicarbonate is an alkalizing agent (14). Therefore, rapid improvement in animal health was observed soon after sodium bicarbonate therapy and the treated animals started defecation, urination and regurgitation after 5-7 hours post treatment, while in the control group, the improvement was observed after 36-48 hours.

\section{References}

1. Nandi, S. and Negi, B.S. (1999). Bovine ephemeral fever: A review. Comp. Immunol. Microbiol. Infect. Dis. 22(2):81-91.

2. Walker, P.J.; Byrne, K.A.; Cybinski, D.H.; Doolan, D.L. and Wang, Y.H. (1991). Proteins of bovine ephemeral fever virus. J. Gen. Virol. 72 ( Pt 1):67-74.

3. Della-Porta, A.J. and Brown, F. (1979). The physico-chemical characterization of bovine ephemeral fever virus as a member of the family Rhabdoviridae. J. Gen. Virol. 44(1):99-112.

4. Walker, P.J. (2005). Bovine ephemeral fever in Australia and the world. Curr. Top. Microbiol. Immunol. 292:57-80.

5. St George, T.D.; Cybinski, D.H.; Murphy, G.M. and Dimmock, C.K. (1984). Serological and biochemical factors in bovine ephemeral fever. Aust. J. Biol. Sci. 37(5-6):341-9.

6. Farag, M.A.; al-Sukayran, A.; Mazloum, K.S. and al-Bukomy, A.M. (1998). Epizootics of bovine ephemeral fever on dairy farms in Saudi Arabia. Rev. Sci. Tech. 17(3):713-22.

7. Zheng, F.Y.; Lin, G.Z.; Qiu, C.Q.; Zhou, J.Z.; Cao, X.A. and Gong, X.W. (2010). Serological detection of bovine ephemeral fever virus using an indirect ELISA based on antigenic site G1 expressed in Pichia pastoris. Vet. J. 185(2):211-5.

8. Hsieh, Y.C.; Cheng, S.H.; Chon, C.C.; Ting, L.J. and Wang, F.I. (2005). Bovine ephemeral fever virus infection in Taiwan (2001-2002). J.Vet.Med.Sci. 67:411-416.

9. Uren, M.F.; St. George, T.D. and Murphy, G.M. (2002). Studies on the pathogenesis of bovine ephemeral fever III: Virological and biochemical data. Vet. Microbiol. 30: 297-307.

10. Strauss J.H. and Strauss, E.G. (2008). Virus penetration. In: Viruses and Human Disease.2nd Ed. P: 1317.

11.Theodorridis, A. and Coetzer, J.A. (1979). Subcutaneous and pulmonary emphysema as complications of bovine ephemeral fever. J.Vet. Res. 46:125-7.

12. Heuschele W.P. (1970). Bovine ephemeral fever. Characteristics of the causative virus. Arch. virol. 30(2-3): 195-202.

13. Nandi, S. and Negi, B.S. (1999). Bovine ephemeral fever: a review. Comparative Immunology, Microbiol. Infect. Dis. 22 (2): 81-91.

14. Wanamaker B.P. and Massey, K.L. (2000). Applied Pharmacology for the Veterinary Technician. 3rd Ed. Saunders Co. pp: 306-7. 